\title{
Palynostratigraphy and palaeoclimatic interpretation of the Plio- Pleistocene Lukundol Formation from the Kathmandu valley, Nepal
}

\author{
*S. Bhandari ${ }^{1}$ and K. N. Paudayal ${ }^{1,2}$ \\ ${ }^{1}$ Central Department of Geology, Tribhuvan University, \\ Kirtipur, Kathmandu, Nepal \\ ${ }^{2}$ Senckenberg, Research Institute and Natural History Museum, \\ Senckenberganlage 25, Frankfurt, Germany \\ (*Email: bhandari_sudarshan@hotmail.com)
}

\begin{abstract}
The Lukundol Formation, a fluvio-lacustrine deposit, constituting the lowermost part of the sedimentary sequence in the Kathmandu valley, is made up of conglomerates in its basal part; thick beds of carbonaceous clay, lignite, silt and sand in the middle part; interbedded clay and gravel in the upper part; and very thick beds of gravel in the uppermost part. Its exposure in the Khahare Khola, near the Lukundol village, is about $205 \mathrm{~m}$ thick. The palynostratigraphy of the Lukundol Formation revealed the dominance of gymnosperms over the angiosperms and herbaceous members. In the pollen diagram, Pinus and Quercus are the predominant taxa whereas Castanopsis and Oleaceae are the next dominant ones. Three fossil pollen zones were differentiated in the Lukundol Formation. Zone I indicates a subtropical climate, zone II belongs to a warm temperate climate, and zone III represents a subtropical to warm-temperate climate.
\end{abstract}

\section{INTRODUCTION}

The Kathmandu valley, one of the largest intermontane basins in the Himalaya, is filled up with the fluvio-lacustrine sediments of Late Pliocene to Holocene age. A comprehensive geological investigation of the Kathmandu basin sediments was carried out by Yoshida and Igarashi (1984), Igarashi et al. (1988), and Yoshida and Gautam (1988). They subdivided the basin sediments into the older-stage deposits (i.e. the Lukundol Formation), middle-stage deposits (i.e. the Boregaon, Chapagaon and Pyanggaon terrace deposits), and younger-stage deposits (i.e. the Gokarna, Thimi and Patan Formations). They also outlined the palaeoclimatic history of the Kathmandu valley. The investigation of lithological succession and palynology was also carried out by a number of other researchers (e.g. VishnuMittre and Sharma 1984, Fuji and Sakai 2002, Paudayal and Ferguson 2004, Paudayal 2005, and Paudayal 2006).

The Lukundol Formation is well exposed in the southern part of the Kathmandu valley and its age ranges from Late Pliocene to Middle Pleistocene (Yoshida and Igarashi 1984; Yoshida and Gautam 1988). The exposure along the Khahare Khola section (Fig. 1) near the Lukundol village is about 205 $\mathrm{m}$ thick. It contains conglomerates with minor amounts of sand and clay lenses at its basal part. Its middle part is made up of thick beds of black to grey organic clay, silt, and sand. In association with these are a number of thick (up to $2 \mathrm{~m}$ ) coal seams (mainly lignite). The upper part of the Lukundol
Formation consists of an interbedding of clay and gravel, whereas the topmost part is represented by very thick gravel beds. The present palynological investigation was carried out on a total of 84 samples collected from the fine sediments comprising the Khahare Khola section (Fig. 2).

\section{MATERIAL AND ANALYTICAL METHODS}

The samples collected for palynological investigation were prepared at the Central Department of Geology, Tribhuvan University, Kirtipur, Kathmandu, following the method described by Zetter (1989). Fossil pollen and spores were extracted from the sediments by treating the sediments with different chemicals such as concentrated $\mathrm{HCl}, \mathrm{HF}$, $\mathrm{CH}_{3} \mathrm{COOH}, \mathrm{KClO}_{3}\left(\mathrm{CH}_{3} \mathrm{CO}\right)_{2} \mathrm{O}, \mathrm{H}_{2} \mathrm{SO}_{4}$, and $\mathrm{ZnBr}_{2}$. The extracted material was then preserved in glycerol for further analysis. At least 200 pollen grains from each sample were point-counted under a light microscope (LM). Some common pollen types in the Lukundol Formation are displayed in Figs. 3, 4, and 5.

\section{DESCRIPTION OF INDIVIDUAL PALYNOMORPHS}

The terminology for the description of pollen and spores was followed from Punt et al. (1994). The individual palynomorphs are described below. 


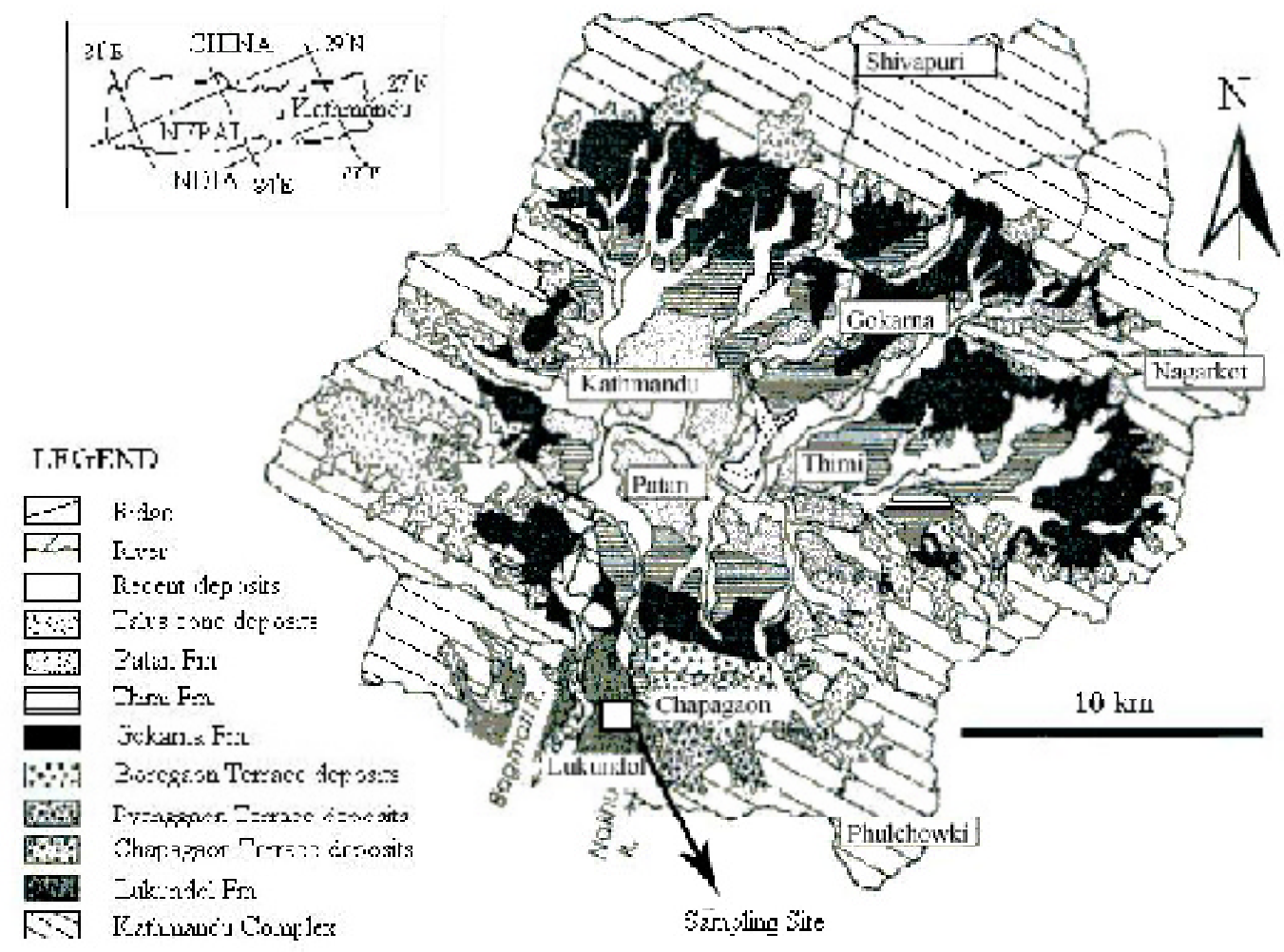

Fig. 1: Geological map of the Kathmandu valley (after Yoshida and Igarashi 1984, Yoshida and Gautam 1988) with location of the palynological sampling within the Lukundol Formation.

\section{Gymnosperms \\ PINACEAE}

Abies sp. (Fig. 3, No. 1)

Shape: Bisaccate

Size: $100-130 \mu \mathrm{m}$, corpus $80 \mu \mathrm{m}$, sacci $50 \mu \mathrm{m}$

Exine in proximal part of corpus is thick (sometimes termed the Abies crest) and coarsely rugulate. Sacci attached almost along full width of the corpus and with distinct alveolae. Sacci and corpus form distinct angle. Corpus attached to the upper half of the sacci.

Picea sp. (Fig. 3, No. 2)

Shape: Bisaccate

Size: $80-110 \mu \mathrm{m}$, corpus $100 \mu \mathrm{m}$, sacci $45 \mu \mathrm{m}$

Corpus faintly and finely verrucate to rugulate and perforate. Sacci finely alveolate. Sacci attached almost along full width of the corpus. Weak angle present between corpus and sacci.

Pinus sp. (Fig. 3, No. 3)

Shape: Bisaccate

Size: $45-60 \mu \mathrm{m}$, corpus $40 \mu \mathrm{m}$, sacci $15-20 \mu \mathrm{m}$
Corpus rugulate and rough. In LM the leptoma smooth (Diploxylon type). Sacci attached almost full width of corpus and coarsely alveolate. The outline of the sacci in the polar view is almost full width of corpus so that the grain seems to consist of three distinct oval parts. Corpus attached to the upper half of the sacci and forms distinct angle with it.

Tsuga sp. (Fig. 3, No. 4)

Shape: Monosaccate, oblate, circular in polar view Size: $60 \mu \mathrm{m}$, saccus $10-15 \mu \mathrm{m}$. Corpus verrucate to rugulate, foveolate and echinate. Saccus echinate and folded.

\section{PODOCARPACEAE}

\section{Podocarpus sp.}

Shape: Bisaccate

Size: $45 \mu \mathrm{m}$, corpus $22-30 \mu \mathrm{m}$, covered with fine spinules or echinate. Sacci faintly alveolate. Sacci attached almost along full width of the corpus. 


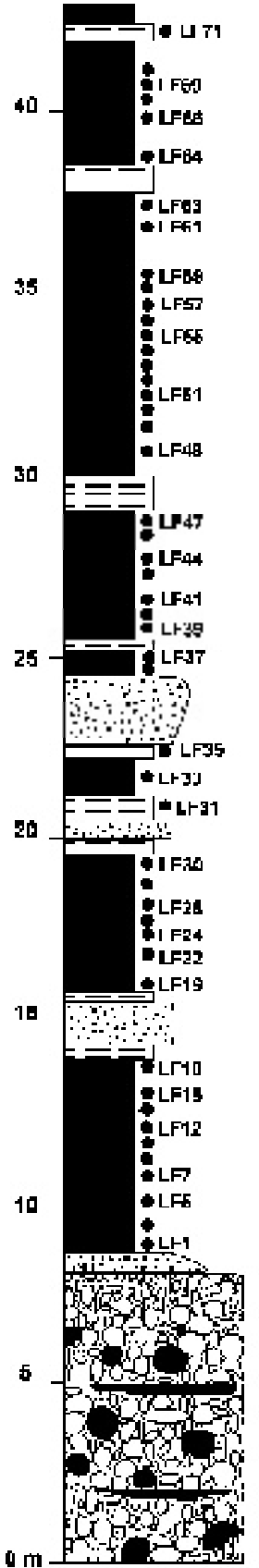

Legend
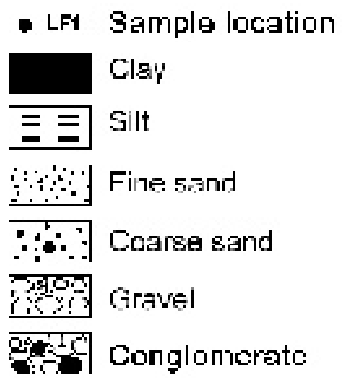

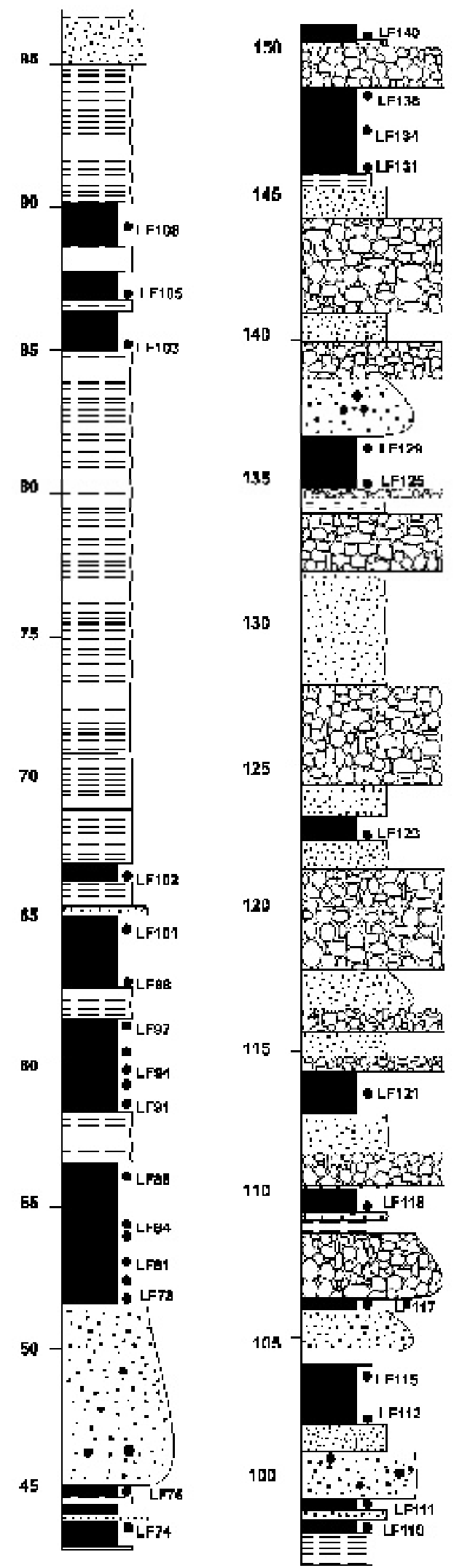

Fig. 2: Columnar section of the Lukundol Formation measured in the Khahare Khola. Sampling sites are also indicated. 

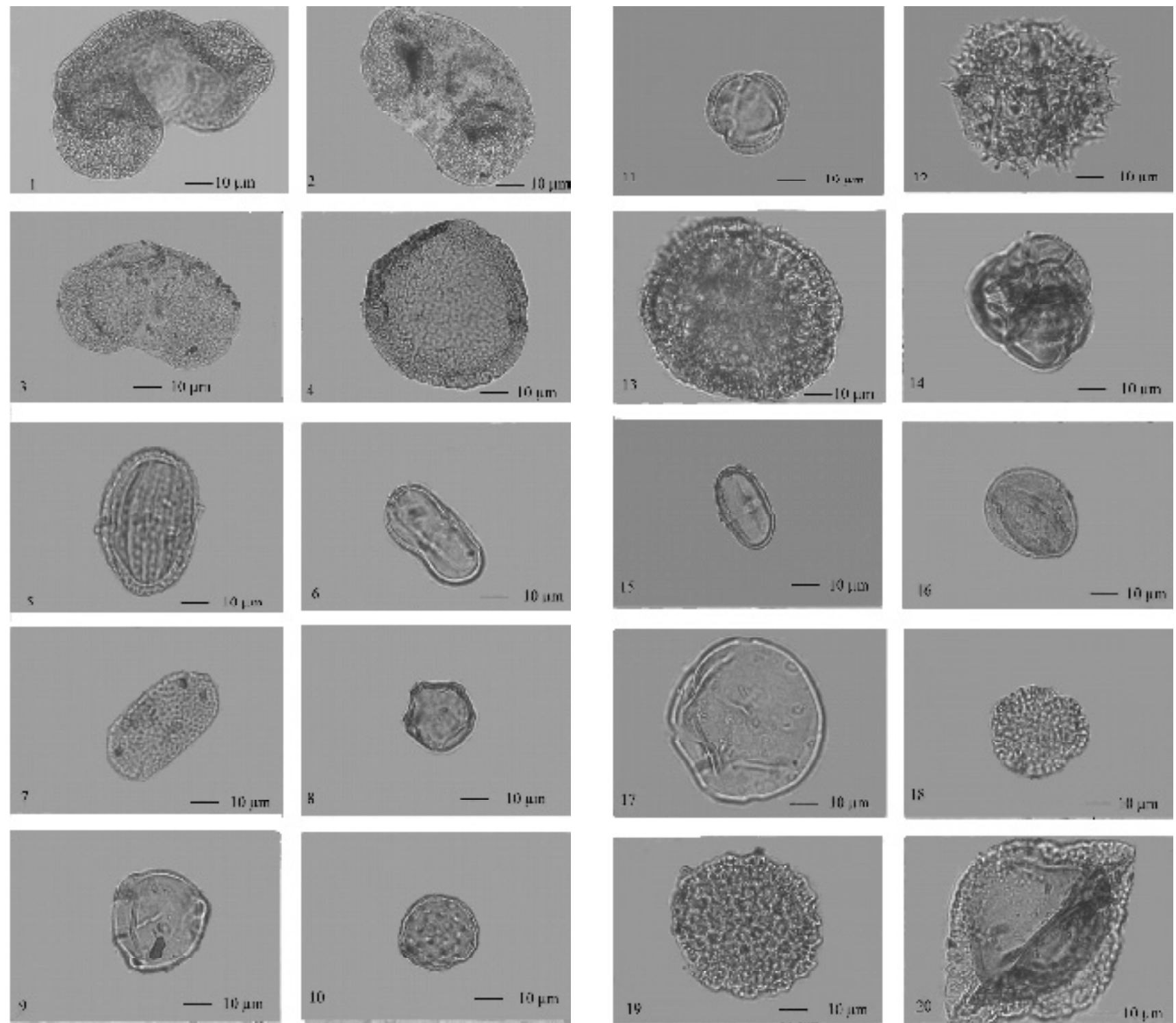

Fig. 3: 1. Abies sp., 2. Picea sp., 3. Pinus sp., 4. Tsuga sp., 5. Strobilanthes sp., 6. Apiaceae gen. indet. 7.Impatiens sp., (equatorial view, LM X 400) 8. Alnus sp., (polar view, LM X 400) 9. Betula sp., 10. Caryophyllaceae, gen. indet. (Equatorial View, LM X 400).
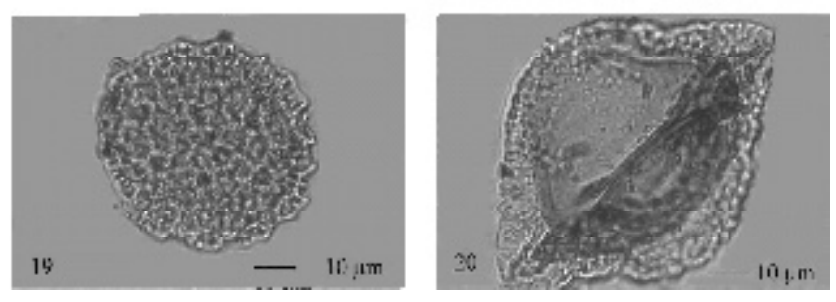

Fig. 4: 11 Artemisia sp., 12. Cruciferae gen. indet. 13. Dipsacaceae, gen. indet. 14. Ericaceae gen. indet. 15. Castanopsis sp., 16. Quercus sp., 17. Juglans sp., 18. Oleaceae gen. indet. 19. Polygonum sp., 20. Trapa sp., (Equatorial View, LM X 400). 

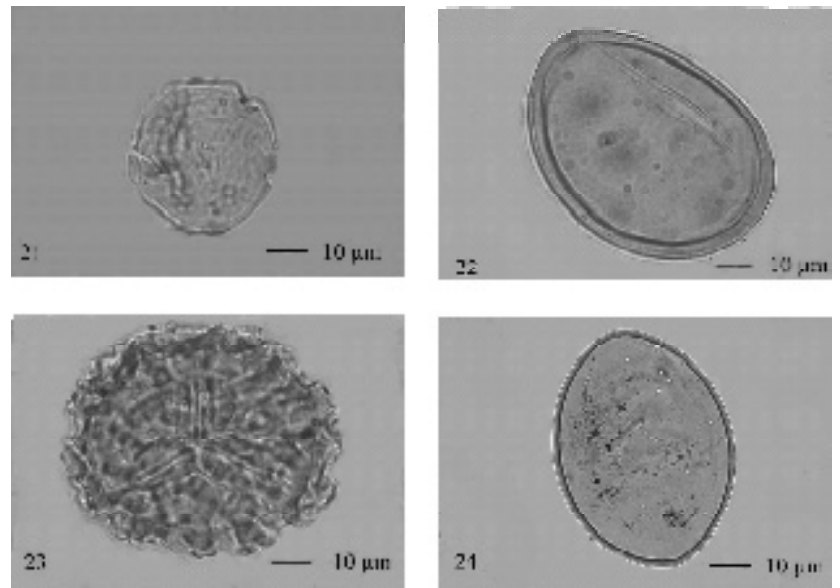

Fig. 5: 21. Ulmus sp., 22. Monolete spore, family indet., 23. Trilete spore, family indet. 24. Algal cysts (Equatorial View, LM X 400)

\section{Angiosperms}

ACANTHACEAE

Strobilanthes sp. (Fig. 3, No. 5)

Shape: Prolate to periprolate.

Size: Polar axis $45 \mu \mathrm{m}$, equatorial axis $21 \mu \mathrm{m}$

Aperture: Tricolporate

Exine: $4 \mu \mathrm{m}$, sexine thicker than nexine, sexine divided into longitudinal stripes, sexine bireticulate, and each longitudinal sexine strip having an uneven coarse reticulum with a depressed reticulated tectum.

\section{Justicia sp.}

Shape: Prolate

Size: Polar axis $24 \mu \mathrm{m}$, equatorial axis $14 \mu \mathrm{m}$

Aperture: Colporate

Exine: $1.5 \mu \mathrm{m}$, sexine as thick as nexine, sexine reticulate, lumina microreticulate, sexine around aperture rugulate, perforate and granulate.

\section{APIACEAE}

Apiaceae gen. indet. (Fig. 3, No. 6)

Shape: Prolate, equatorial part slightly constricted.

Size: $17-24 \mu \mathrm{m}$, equatorial axis $8-10 \mu \mathrm{m}$

Aperture: Tricolporate, endoaperture elongate, colpi long reaching almost to the poles.

Exine: $1 \mu \mathrm{m}$, rugulate, shortly striate and granulate.

\section{AQUIFOLIACEAE}

Ilex sp.

Shape: Prolate, sub circular in polar view

Size: Polar axis $36 \mu \mathrm{m}$, equatorial axis $24 \mu \mathrm{m}$

Aperture: Tricolporoidate

Exine: $3 \mu \mathrm{m}$, atectate, clavate and pilate, pila with fine striate ornamentation.

\section{BALSAMINACEAE}

Impatiens sp. (Fig. 3, No. 7)

Shape: Spheroidal, rectangular in polar view

Size: Equatorial axis $33 \mu \mathrm{m}$

Aperture: Tetracolpate, colpi short

Exine: $1.5 \mu \mathrm{m}$. sexine as thick as nexine, reticulate, rudimentary columellae are present in lumina.

\section{BETULACEAE}

Alnus sp. (Fig. 3, No. 8)

Shape: Oblate, penta-angular in polar view

Size: Polar and equatorial axis 22-24 $\mu \mathrm{m}$.

Aperture: Pentaporate, pori vestibulum type, neighbouring pori connected by archs or bands of nexious thickening.

Exine: $1.5 \mu \mathrm{m}$, tectum consists of irregular rugulae with very small spinules (microechinate). Sexine slightly thicker than nexine.

\section{Betula sp. (Fig. 3, No. 9)}

Shape: Oblate, triangular in polar view

Size: $21 \mu \mathrm{m}$

Aperture: Triporate occasionally tetraporate, pores circular and vestibulum type, sexine with tectum clearly thickest at the apex, vestibulum forming a well-defined annulus.

Exine: $2 \mu \mathrm{m}$, sexine consists of irregular rugulae with very small spinules.

\section{CARYOPHYLLACEAE}

Caryophyllaceae gen. indet. (Fig. 3, No. 10)

Shape: Spheroidal

Size: $24-27 \mu \mathrm{m}$

Aperture: Pantoporate, pori circular

Exine: $2 \mu \mathrm{m}$, sexine as thick as nexine, sexine perforated, spinulate, pore membrane spinulate.

\section{CHENOPODIACEAE}

Chenopodiaceae gen. indet.

Shape: Spheroidal

Size: $20 \mu \mathrm{m}$

Aperture: Pantoporate, pore circular

Exine: $1 \mu \mathrm{m}$, sexine thicker than nexine, sexine spinulate, perforate, mesoporium raised above pori, pore membrane spinulate, granulate.

\section{COMPOSITAE}

Artemisia sp. (Fig. 4, No. 11)

Shape: Prolate, circular in polar view.

Size: Polar axis $20 \mu \mathrm{m}$

Aperture: Tricolporate, colpi nearly as long as polar axis.

Exine: $3 \mu \mathrm{m}$, sexine much thicker than nexine, distinctly stratified, sexine in mesocolpium thicker than in the colpi area forming a margo, sexine microechinate and granulate, granules uniformly distributed between the spinules. 
Compositae gen. indet. (Fig. 4, No. 12)

Shape: Suboblate

Size: $35-40 \mu \mathrm{m}$

Aperture: Tricolporate

Exine: 6-7 $\mu \mathrm{m}$ (with pores), sexine thick, perforate and echinate, the basal part of spine broadly perforate with perforations of various shape and sizes, surface granulate, spines $2-3 \mu \mathrm{m}$ in length.

\section{CONVOVULACEAE}

Convovulaceae gen. indet.

Shape: Subprolate

Size: $46.5 \mu \mathrm{m}$

Aperture: Tricolpate

Exine: $3.5 \mu \mathrm{m}$. sexine much thicker than nexine, baculate, bacula coalesce to form striato-reticulate pattern towards periphery.

\section{CRUCIFERAE}

Cruciferae gen. indet.

Shape: Prolate-Spheroidal

Size: $35 \mu \mathrm{m}$

Aperture: Tricolpate

Exine: $3 \mu \mathrm{m}$. sexine as thick as nexine, retipilate. Nontogillate.

\section{DIPSACACEAE}

Dipsacus sp. (Fig. 4, No. 13)

Shape: Oblate to spheroidal

Size: Equatorial axis $65 \mu \mathrm{m}$

Aperture: Tricolpate, colpi short and broad.

Exine: $7 \mu \mathrm{m}$, sexine very thick and divided into two layers, sexine echinate and microechinate, perforate and granulate, spines are of two types, larger $(>1 \mu \mathrm{m})$ and smaller $(<1 \mu \mathrm{m})$, larger spines are stupa-shaped, less abundant than smaller spinules.

\section{ELAEAGNACEAE}

\section{Elaeagnus sp.}

Shape: Suboblate, angular in polar view

Size: $28-33 \mu \mathrm{m}$

Aperture: Tricolporate, colpi are short.

Exine: 3-4 $\mu \mathrm{m}$, nexine is slightly thicker than sexine, pore cavity is broad, sexine slightly rugulate and perforate.

\section{ERICACEAE}

Ericaceae gen. indet. (Fig. 4, No. 14)

Shape: Tetrahedral tetrads

Size: $35 \mu \mathrm{m}$

Aperture: Tetrads tricolporate

Exine: $2.5 \mu \mathrm{m}$, sexine slightly thicker than nexine, psilate.

\section{EUPHORBIACEAE}

Euphorbiaceae gen. indet.

Shape: Prolate, semicircular and lobate in polar view.
Size: Polar axis $38 \mu \mathrm{m}$, equatorial axis $30 \mu \mathrm{m}$

Aperture: Tricolporate, colpi long and broad.

Exine: $4 \mu \mathrm{m}$, sexine thicker than nexine, microreticulate to perforate, size of luminae uniform throughout the surface of the grain, muri broader than lumina and sparsely granulated.

\section{FAGACEAE}

Castanopsis sp. (Fig. 4, No. 15)

Shape: Prolate, circular and lobate in polar view

Size: Polar axis $25 \mu \mathrm{m}$, equatorial axis $12 \mu \mathrm{m}$

Aperture: Tricolporate, colpi nearly as long as polar axis.

Exine: Striate with irregularly distributed rods, in $1-2 \mu \mathrm{m}$ length.

\section{Quercus sp. (Fig. 4, No. 16)}

Shape: Prolate.

Size: Polar axis 20-24 $\mu \mathrm{m}$, equatorial axis $15-21 \mu \mathrm{m}$

Aperture: Tricolporate

Exine: $1-1.5 \mu \mathrm{m}$, tectum consists of rounded to sub rounded elements fused together to form clusters of microverrucae distributed all over the surface of the grain.

\section{GENTIANACEAE}

Nymphoides sp.

Shape: Oblate, semi-circular in polar view

Size: Equatorial axis $30 \mu \mathrm{m}$

Aperture: Syncolpate

Exine: Sexine as thick as nexine, surface coarsely striate, striae irregularly arranged, abruptly truncated and occasionally branched.

\section{HALORAGACEAE}

Myriophyllum sp.

Shape: Oblate, pentangular in polar view

Size: Equatorial axis $25 \mu \mathrm{m}$

Aperture: Pentaporate, pori annulate and oval

Exine: $1-1.5 \mu \mathrm{m}$, sexine slightly thicker than nexine, marginate and granulate.

\section{JUGLANDACEAE}

Juglans sp. (Fig. 4, No. 17)

Shape: Oblate, (sub spherical to spheroidal) and circular Size: $40-42 \mu \mathrm{m}$

Aperture: Panporate, pores aspidate, circular rarely oval, $2-3 \mu \mathrm{m}$. Exine: $2 \mu \mathrm{m}$, sexine is thicker than nexine, tectum is microechinate.

\section{MYRICACEAE}

Myrica sp.

Shape: Oblate, triangular in polar view

Size: $17 \mu \mathrm{m}$

Aperture: Triporate

Exine: $1 \mu \mathrm{m}$, sexine is thicker than nexine near and around pori, sexine regularly microechinate. 


\section{OLEACEAE}

Fraxinus sp.

Shape: Prolate, circular in polar view.

Size: Polar axis $18-20 \mu \mathrm{m}$, equatorial axis about $19 \mu \mathrm{m}$.

Aperture: Tricolporate

Exine: $1 \mu \mathrm{m}$, sexine is thicker than nexine, reticulate, lumina heterobrochate, muri distinctly segmented.

Oleaceae gen. indet. (Fig. 4, No. 18)

Shape: Prolate, circular and lobate in polar view

Size: $20 \mu \mathrm{m}$

Aperture: Tricolporate

Exine: $1 \mu \mathrm{m}$, sexine is thicker than nexine, reticulate, lumina heterobrachate, muri irregularly segmented.

\section{POACEAE}

Poaceae gen. indet.

Shape: Spheroidal

Size: $35 \mu \mathrm{m}$.

Aperture: Ulcerate, pore annulate, diameter of the pore $2-3 \mu \mathrm{m}$ Exine: $1 \mu \mathrm{m}$, sexine as thick as nexine, microverrucate with small spiny elements especially at the edges of the microverrucae.

\section{POLYGONACEAE}

Polygonum sp. (Fig. 4, No. 19)

Shape: Spheroidal.

Size: $51-55 \mu \mathrm{m}$.

Aperture: Pantoporate

Exine: $6 \mu \mathrm{m}$, sexine as thick as nexine, reticulate, columella relatively long, thin and closely packed, lumina with numerous rudimentary columellae.

\section{RANUNCULACEAE}

Ranunculaceae gen. indet.

Shape: Prolate, circular and lobate in polar view

Size: Polar axis $38 \mu \mathrm{m}$, equatorial axis $28 \mu \mathrm{m}$

Aperture: Tricolpate, colpi broad and almost as long as polar axis

Exine: $3 \mu \mathrm{m}$, sexine thicker than nexine, sexine much thicker in masocolpium (crescentic), sexine microechinate, foveolate, perforate and granulate.

\section{TRAPACEAE}

Trapa sp. (Fig. 4, No. 20)

Shape: Prolate-Spheroidal, equatorial view rhombic, polar view triangular obtuse

Aperture: Triporate with a collar of sexine

Exine: $4 \mu \mathrm{m}$ at poles and $7 \mu \mathrm{m}$ at the equator, sexine thicker than nexine microclavate. Microclavae variable in size.

\section{ULMACEAE}

Ulmus sp. (Fig. 5, No. 21)

Shape: Oblate, pentagonal in polar view

Size: $21-28 \mu \mathrm{m}$

Aperture: Pantoporate

Exine: $1 \mu \mathrm{m}$, sexine is thicker than nexine, sexine rugulate and covered by nano-granules.

\section{PTERIDOPHYTE SPORES}

Family indet. (Fig. 5, No. 22)

Shape: Elliptical

Size: $74 \mu \mathrm{m}$

Aperture: Monolete

Exospore: $2 \mu \mathrm{m}$, psilate with occasional nano-granules.

Family indet. (Fig. 5, No. 23)

Shape: Rounded

Size: $40 \mu \mathrm{m}$

Aperture: Trilete

Exospore: $1.5 \mu \mathrm{m}$, spinose and granulose, spines irregularly distributed and clustered to form ridges of the spines.

Algal cysts (Fig. 5, No. 24)

\section{RESULTS OF PALYNOLOGICAL ANALYSIS}

The gymnosperms consist of Pinus, Picea, Abies, and Tsuga. The woody angiosperm trees and shrubs contain Quercus, Castanopsis, Alnus, Justicea, Oleaceae etc. Artemisia, Chenopodiaceae, Compositae, Caryophyllaceae, Ranunculaceae etc. are the major herbs. The aquatic plants are Nymphoides, Myriophyllum and Trapa. The fern spores are monolete and trilete. The pollen diagram of the Lukundol Formation is basically divided into three pollen assemblage zones (Fig. 6).

\section{Zone Luku-I}

This zone is characterised by a high percentage of Pinus and Quercus. Pinus attains (13-70\%) of the total count. The other conifers are Picea $(0.5-4.5 \%)$ and Abies $(<3 \%)$. The angiosperm trees such as Quercus (5-35\%) and Castanopsis $(10-12 \%)$ are the major constituents. The other broad-leaved trees and shrubs such as Juglans $(<1 \%)$, Oleaceae $(1-7 \%)$, and Fraxinus $(<1 \%)$ occur as minor elements. Most of the herbaceous pollen originates from Compositae $(2 \%)$, Artemisia (2\%), Chenopodiaceae (1\%), Poaceae (1-5\%), and Caryophyllaceae. The aquatic plants are Nymphoides (1$5 \%)$ and Trapa (1-2\%). The fern spores attain a very high percentage of the total count.

\section{Zone Luku-II}

This zone is characterised by a decline in Quercus and Castanopsis and increase in the percentage of Pinus. Of the gymnosperms, Pinus (3-70\%) is the dominant genus whereas 


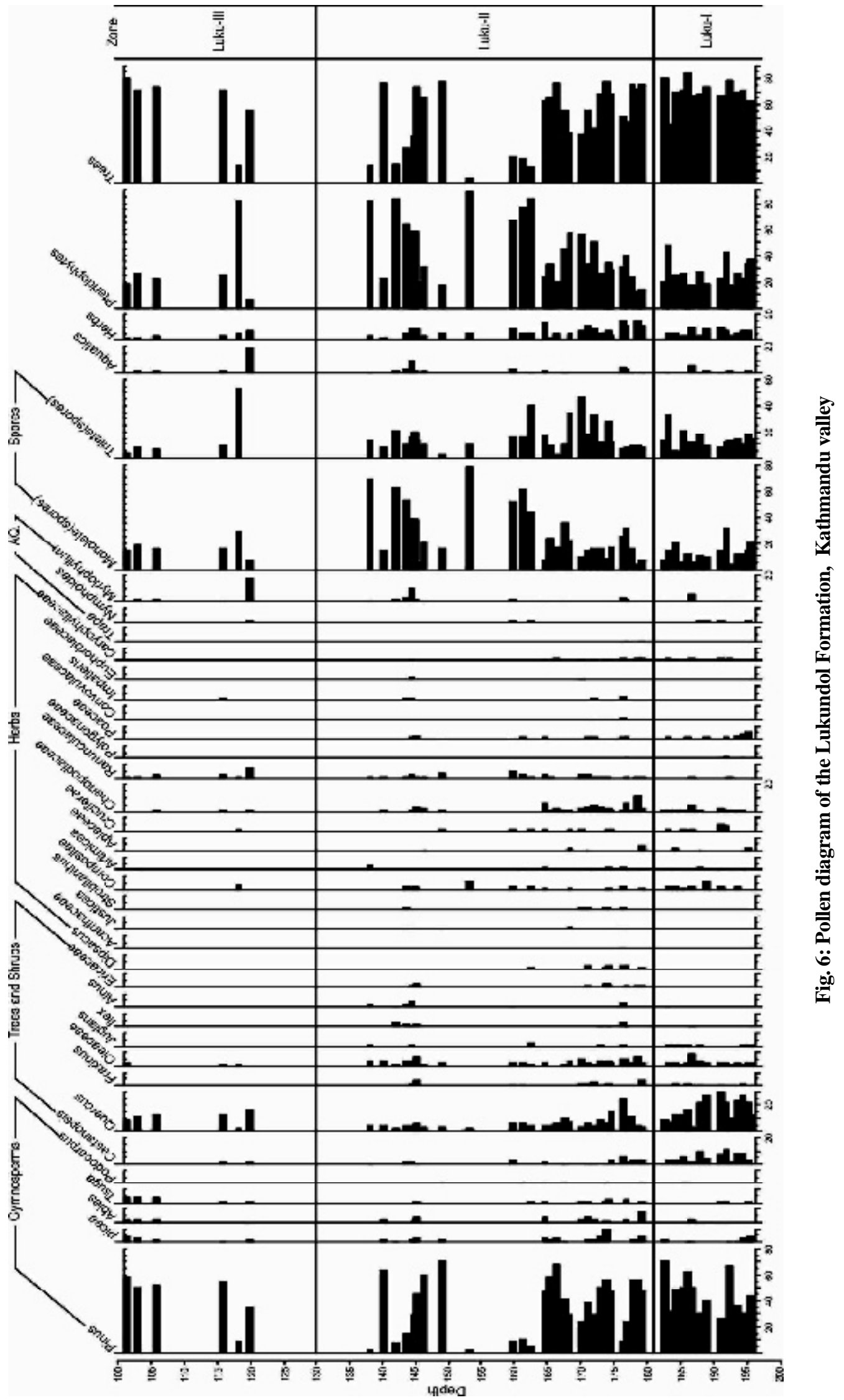


Picea (1-10\%), Abies (1-18\%), and Tsuga $(<2.5 \%)$ are the minor elements. Quercus $(2-2.5 \%)$ and Castanopsis $(<5 \%)$ are the major broad-leaved trees. The minor trees are Juglans $(1 \%)$, Alnus $(<3 \%)$, Ericaceae $(<3 \%)$, and Betula $(<2 \%)$. Compositae $(0.5-8 \%)$, Ranunculaceae $(1-5 \%)$, and Chenopodiaceae $(1-10 \%)$ are the common herbs. The fern spores are the common elements.

\section{Zone Luku-III}

This zone is represented by an increase in the percentage of Quercus and decrease in Pinus. Quercus is more abundant (2-30\%), Castanopsis and Oleaceae are also present in minor elements. The conifers such as Pinus constitute (10-58\%) of the total count, whereas Picea (4.5\%), Abies (<3\%) and Tsuga (4\%) are the minor elements.

\section{PALAEOCLIMATIC INTERPRETATION}

In order to reconstruct the palaeoclimate of the Lukundol Formation, 27 families and 35 genera were used as shown in the pollen diagram (Fig. 6). The following genera were used as the main indicators of palaeoclimate: Pinus of cold climate, Quercus and Castanopsis of warm climate and Alnus of wet climate (Fuji and Sakai 2002). According to the pollen assemblage and changes of frequency in the pollen diagram, the palaeoclimatic record was divided into three main periods corresponding to the above three pollen zones.

In the pollen assemblage zone Luku-I, Pinus was the dominant species. Other gymnosperms such asPicea,Abies, Tsuga and Podocarpus were present in a very small amount. The angiosperm trees Quercus, Castanopsis, and Oleaceae were distributed throughout this zone, indicating a warm climate. Since the coniferous trees (Pinus) were found to be growing in a subtropical climate and the presence of an oak forest indicated similar climatic conditions. Based on the above vegetation pattern, it was inferred that a subtropical climate prevailed during the development of this zone.

Major changes in vegetation in the Lukundol Formation commenced in the pollen assemblage zone Luku-II. Pinus was the most dominant genus. Other gymnosperms, such as Picea,Abies, and Tsuga were also present in considerable amounts. It is noteworthy that Picea and Abies show a cold as well as dry climate. There was a gradual decrease in the angiosperm trees, such as Quercus and Castanopsis. The presence of Juglans and Betula also pointed to a cold and dry climate. Therefore, from the above vegetation information, this zone was inferred to be formed in a warmtemperate climate.

In the pollen assemblage zone Luku-III, againPinus was the dominant genera. Picea, Abies, and Tsuga were present in less than $5 \%$ of the total pollen count. There was a rapid increase in the proportion of Quercus and is distributed throughout the zone. Castanopsis was also present in some horizons. The presence of woody angiosperms as well as gymnosperms give information that the climate was subtropical to warm temperate.

Some of the sections in the pollen assemblage zones Luku-II and Luku-III were barren. There was a deposition of finer sediments up to a height of $104.5 \mathrm{~m}$ from the base of the Lukundol Formation and the pollens were also abundant except in few horizons. But, after this level there was a drastic change in the deposition. The river system changed and the gravel, sand, and clay beds were deposited successively. Because of the coarse nature of sediments and subsequent oxidation, the pollen was not preserved.

\section{CONCLUSIONS}

The Lukundol Formation had a series of major and minor clastic events related to the uplift of the hinterland. These events interrupted the palynological information and gave a taphonomically biased picture. The Lukundol Formation can be divided into three pollen zones according to the percentage of gymnosperms and angiosperms. Zone-I was characterised by a subtropical climate, zone-II had a warmtemperate climate, and zone-III was formed in a subtropical to warm-temperate climate. The gymnosperms dominated over the woody angiosperms during the deposition of the Lukundol Formation. Hence, the pollen assemblages in this formation had a warm-temperate signature. A comparison of the past and present-day vegetation in the study area revealed that the Lukundol Formation was deposited in a climate warmer than the present time.

\section{ACKNOWLEDGEMENTS}

We express our sincere gratitude to Prakash Chandra Adhikary, Head of Central Department of Geology for his kind support and encouragement to carry out this research. We would like to thank Dayananda Bajracharya, former vicechancellor of Nepal Academy of Science and Technology, for granting to use the light microscope for the identification of palynomorphs. We acknowledge R. P. Chaudhary for his comments and suggestions. Thanks are extended to Chinese Academy of Sciences (CAS) and the Third World Academy of Sciences (TWAS) for CAS-TWAS fellowship which enable KNP to visit Institute of Botany, Chinese Academy of Sciences, Beijing, for the light microscopic photography.

\section{REFERENCES}

Fuji, R. and Sakai, H., 2002, Palynological study of the drilled sediments from the Kathmandu Basin and its palaeoclimatic and sedimentological significance. Jour. Nepal Geol. Soc., v. 25 (Sp. Issue.), pp. 53-61.

Igarashi, Y., Yoshida, M., and Tabata, H., 1988, History of vegetation and climate in the Kathmandu valley. Proc. Indian National Sci. Acad., v. 54A(4), pp. 550-563.

Paudayal, K. N. and Ferguson, D. K., 2004, Pleistocene palynology of Nepal. Quaternary International, v. 117, pp. 69-79. 
Paudayal, K. N., 2005, Late Pleistocene pollen assemblages from the Thimi Formation, Kathmandu valley, Nepal. The Island Arc, v. 14(4), pp. 328-337.

Paudayal, K. N., 2006, Late Pleistocene pollen assemblages from the Gokarna Formation (Dhapasi section) in Kathmandu valley, Nepal. Jour. Nepal Geol. Soc., v. 33, pp.13-18.

Punt, W., Blackmore, S., Nilsson, S., and Le Thomas A., 1994, Glossary of pollen and spore Terminology. LPP Foundation, Utrecht, the Netherlands, $71 \mathrm{p}$.

Vishnu-Mittre and Sharma, C., 1984, Vegetation and climate change during the Last Glaciation in the Kathmandu valley, Nepal. Pollen et Spores, v. 26(1), pp. 69-94.
Yoshida, M. and Gautam, P., 1988, Magnetostratigraphy of PlioPleistocene lacustrine deposits in the Kathmandu valley, Central Nepal. Proc. Indian National Sci. Acad., v. 54A(3), pp. 410-417.

Yoshida, M. and Igarashi, Y., 1984, Neogene to Quaternary lacustrine sediments in the Kathmandu valley, Nepal. Jour. Nepal Geol. Soc., v. 4 (Sp. Issue), pp. 73-100.

Zetter, R., 1989, Methodik und bedeutung einer routinemaessig kombinierten lichtmikroskopischen und rasterelektronmikroskopischen untersuchung fossiler mikrofloren. Courier Forschungsinstitut Senckenberg, Frankfurt am Main, v. 109, pp. 41-50. 